\title{
Effect of plant harvesting on the performance of constructed wetlands during winter: radial oxygen loss and microbial characteristics
}

Qian Wang, Huijun Xie, Jian Zhang, Shuang Liang, Huu Hao Ngo, Wenshan Guo, Chen Liu, Congcong Zhao, Hao Li

Q. Wang, J. Zhang (*), S. Liang, C. Liu, C. Zhao, H. Li: Shandong Key Laboratory of Water Pollution Control and Resource Reuse, School of Environmental Science and Engineering, Shandong University, Jinan 250100, China, e-mail: zhangjian00@sdu.edu.cn

H. Xie: Environmental Research Institute, Shandong University, Jinan 250100, China

H. H. Ngo, W. Guo: School of Civil and Environmental Engineering, University of Technology Sydney,

Broadway, NSW 2007, Australia

\begin{abstract}
The aboveground tissue of plants is important for providing roots with constant photosynthetic resources. However, the aboveground biomass is usually harvested before winter to maintain the permanent removal of nutrients. In this work, the effects of harvest on plants' involvement in oxygen input as well as in microbial abundance and activity were investigated in detail. Three series of constructed wetlands with integrated plants ("unharvested"), harvested plants ("harvested"), and fully cleared plants ("cleared") were set up. Better performance was found in the unharvested units, with the radial oxygen loss (ROL) rates ranging from 0.05 to $0.59 \mu \mathrm{mol} \mathrm{O}_{2} / \mathrm{h} /$ plant, followed by the harvested units that had relatively lower ROL rates ( 0.01 to $0.52 \mu \mathrm{mol} \mathrm{O}$ /h/plant). The cleared units had the lowest removal efficiency, which had no rhizome resources from the plants. The microbial population and activity were highest in the unharvested units, followed by the harvested and cleared units. Results showed that bacterial abundances and enhanced microbial activity were ten times higher on root surfaces compared with sands. These results indicate that late autumn harvesting of the aboveground biomass exhibited negative effects on plant ROL as well as on the microbial population and activity during the following winter.
\end{abstract}

\section{Keywords}

Harvesting, Constructed wetlands, Radial oxygen loss, Microbial population, Microbial activity 


\section{Introduction}

Given their inexpensive cost and low power consumption, constructed wetlands (CWs) are increasingly used for wastewater treatment (Vymazal 2010). Plants, as the primary components of CWs, possess an important role in pollutant removal because of their uptake, storage, and release processes (Dickopp et al. 2011). However, the removal efficiency of CWs is challenged during winter with the reduced biological removal pathways and nutrients released because of plant decay (Kadlec and Wallace 2008, Wang et al. 2012a). The aboveground biomass of plants in CWs is usually harvested before winter to maintain permanent pollutant removal (Granéli et al. 1992; Jinadasa et al. 2008).

Aboveground tissue is important for nutrient storage and removal processes in wetlands (Toet et al. 2005). Plant shoots in the water column can decrease the current velocity of the through-flowing water and are critical for the delivery of oxygen and organic compounds from aboveground organs to belowground parts. Thus, aboveground biomass harvesting may affect the plant itself and the removal processes (Asaeda and Karunaratne 2000; Asaeda et al. 2006). Plants react promptly to disturbances to their internal equilibrium (Valkama et al. 2008). Therefore, we speculated that the influences of plant physiological changes caused by harvesting on the following winter removal efficiency could not be neglected.

Plants' involvement in oxygen input is important for the activity and types of metabolism performed by microorganisms (Stottmeister et al. 2003). Some of the photosynthetic oxygen produced in the leaves of emergent plants and the atmospheric oxygen entering the shoots by diffusion via the stomata are transported to underground tissues through aerenchymal tissues (Armstrong et al. 1992; Armstrong 1978). Some of the oxygen is consumed during root respiration or transported back into the atmosphere; the remaining oxygen is leaked from the root region to the rhizosphere in a process called radial oxygen loss (ROL) (Brix and Schierup 1990; Tanaka et al. 2007). Thus, ROL causes the oxygen concentration to be much higher in the rhizosphere than in the surrounding soil (Van Bodegom et al. 2001). Oxygen leakage has a significant impact on important mechanisms of wastewater treatment in CWs, including its influence on the redox potential (Białowiec et al. 2012) and its enhancement of microbial activity (Ueckert et al. 1990).

Tanaka et al. (2007) found that plants with open dead culms have higher ROL rates than those with sealed dead culms. However, the higher oxygen transport through open dead culms is more pronounced under windy conditions (Armstrong et al. 1992). Therefore, harvesting has a potential influence on the oxygen leakage from plants. The ROL rates in the present study were detected during harvesting operations. Microbial abundance and activity were also investigated to gain insights into the environmental impact of harvesting.

Three series of wetlands with integrated plants, harvested plants, and fully cleared plants were set up. We directly quantified the ROL rates and analyzed the microbial population and activity using quantitative polymerase chain reaction (qPCR) assays based on 16S rRNA and the functional ammonia-monooxygenase (amoA) gene. This study aimed to provide a 
theoretical understanding of the effects of harvesting on wetland performance in the subsequent winter.

\section{Materials and methods}

\section{Site description and operation}

Experiments were performed in nine independent microcosm wetland systems located in Shang Dong Normal University in Jinan, China ( $36^{\circ} 40^{\prime} 36^{\prime \prime} \mathrm{N}, 117^{\circ} 3^{\prime} 42^{\prime \prime} \mathrm{E}$ ), which had a warm-temperature monsoonal climate. The microcosm wetland systems were set up using a subsurface flow design for treating domestic wastewater on March 2, 2012. The treatment cells were polyvinyl chloride column (48 cm deep and $30 \mathrm{~cm}$ in diameter) filled with $15 \mathrm{~mm}$ gravel and washed sand (particle size $<2 \mathrm{~mm}$ ) to depths of 5 and $35 \mathrm{~cm}$, respectively (Fig. 1). Each cell was planted with Phragmites australis, which was transplanted from Nansi Lake. The plant density was 17 rhizomes per cell. The microcosms were fed synthetic wastewater to simulate the post-primary (B) domestic wastewater effluent (Taylor et al. 2011). The influent with $14.45 \pm 0.24 \mathrm{mg} / \mathrm{L}$ ammonia nitrogen $\left(\mathrm{NH}_{4}{ }^{+}-\mathrm{N}\right)$ and $59.38 \pm 4.08 \mathrm{mg} / \mathrm{L}$ chemical oxygen demand (COD) was pumped into the cells to keep the water level below the sand surfaces. Each wetland was batch-operated for 7 days. Plants were grown for 8 months before harvesting. By the end of autumn (November 24, 2012), plant shoots were harvested in three cells ("harvested" group); then, both plant shoots and roots were harvested in another three cells ("cleared" group), and the remaining cells with unharvested plants were used as the controls ("unharvested" group). The day of the harvest was deemed the first day of this study.

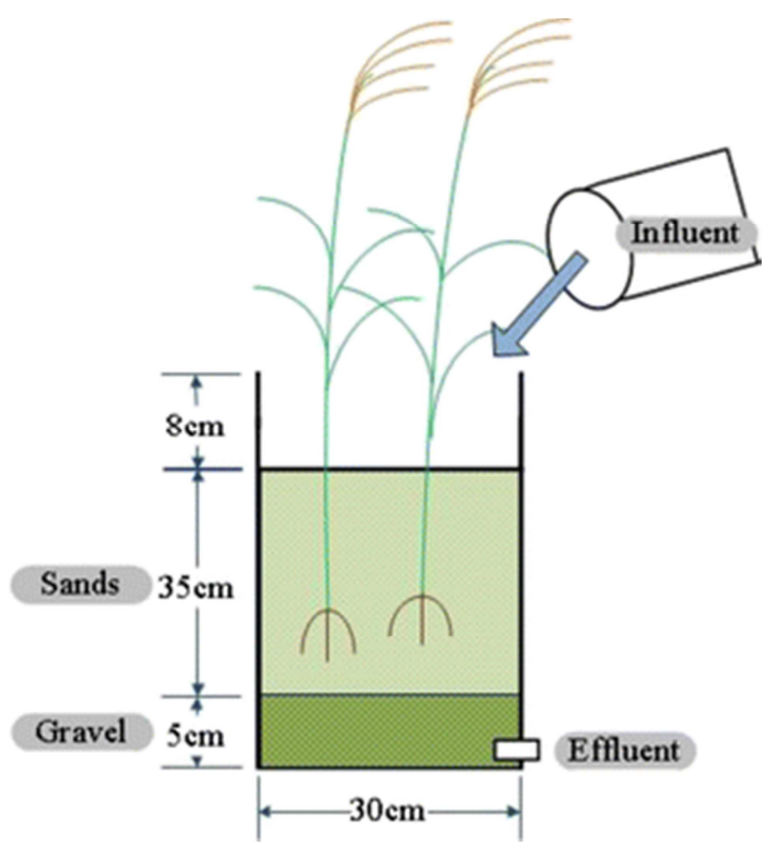

Fig. 1 Profile of the pilot-scale constructed wetland unit 


\section{Sampling}

The dissolved oxygen (DO) and temperature (T) of the influent and effluent were measured every 7 days. At the seventh day of each cycle, the influent and effluent water samples were collected and stored in sterile plastic bottles. The water samples were immediately brought to the lab and stored at $4{ }^{\circ} \mathrm{C}$ before chemical analysis.

The ROL rates were tested at different temperature stages, namely, 9.43 $\pm 0.60,8.48 \pm 2.58$, $5.56 \pm 1.78$, and $2.40 \pm 1.45^{\circ} \mathrm{C}$, corresponding to the 14th, 21st, 28th, and 42nd day of the experiment. Undamaged plants were removed from the microcosm to quantify the ROL rate. The plants were carefully separated from the debris and cultivated in the same simulated wastewater environment before measurement.

The wetlands were pre-cultured for 8 months before the 42-day experiment. Sand and root samples were obtained for DNA and RNA extraction from each microcosm at the end of the experiment (on the 42nd day). Each microcosm was completely drained before the sand samples were collected from the top layer $(5$ to $10 \mathrm{~cm}$ ) in five different plots (Calheiros et al. 2010). Subsequently, the plants were removed and separated from any residues by shaking the plant in a container of sterile water. Roots of approximately 0.5 to $1 \mathrm{~mm}$ in diameter near the root tips (Faulwetter et al. 2013) were aseptically excised from the plant. Both the sand and root samples were stored in 5-mL aseptic Eppendorf tubes, immediately placed on ice, and stored at $-80{ }^{\circ} \mathrm{C}$ before microbial analysis.

\section{Analysis}

\section{Chemical analysis}

Laboratory analysis was performed on the water samples to determine the COD and ammonium $\left(\mathrm{NH}_{4}{ }^{+}-\mathrm{N}\right)$ content. Water temperature and DO were measured using a DO meter (HQ30d 53LEDTM; HACH, USA). All the aforementioned parameters were determined according to standard methods (APHA 2002).

\section{Microbial analysis}

\section{DNA and RNA extraction}

DNA and RNA were extracted using the respective MOBIO PowerSand ${ }^{\mathrm{TM}}$ DNA and RNA Isolation Kits, according to the manufacturer's instructions. DNA and RNA yields were measured with a NanoDrop ND-1000 UV-vis spectrophotometer (NanoDrop Technologies, Wilmington, $\mathrm{DE}, \mathrm{USA})$. The absorbance ratio $\left(\mathrm{A}_{260} / \mathrm{A}_{280}\right)$ was used to assess protein contamination and their purity. Their integrity was evaluated using formaldehyde denaturing agarose gels. Complementary DNA (cDNA) was generated using the superscript reverse transcriptase (TaKaRa, Japan). The reverse transcription mixture contained $4 \mu \mathrm{L}$ of $5 \times$ PrimeScript ${ }^{\circledR}$ Buffer 2 (for real-time PCR), $1 \mu \mathrm{L}$ of PrimeScript ${ }^{\circledR}$ RT Enzyme Mix 1, $1 \mu \mathrm{L}$ of RT Primer Mix, $10 \mu \mathrm{L}$ of template RNA ( $\leq 100 \mathrm{ng}$ ), and up to $20 \mu \mathrm{L}$ of RNase-Free $\mathrm{dH}_{2} \mathrm{O}$ (TaKaRa, Japan). The reverse transcription PCR 
program is shown in Table 1 . The DNA and cDNA products were stored at $-20{ }^{\circ} \mathrm{C}$ before $\mathrm{qPCR}$ analysis.

Table 1 PCR programs used in this study

\begin{tabular}{|c|c|}
\hline Application & PCR Program \\
\hline amoA gene cloning & $\begin{array}{l}\text { Initial denaturation for } 60 \mathrm{~s} \text { at } 94{ }^{\circ} \mathrm{C} \text {, followed by } 35 \text { cycles of } 94{ }^{\circ} \mathrm{C} \text { for } 60 \mathrm{~s}, 54{ }^{\circ} \mathrm{C} \text { for } \\
60 \mathrm{~s} \text {, and } 72{ }^{\circ} \mathrm{C} \text { for } 3 \mathrm{~min} \text {. The program ended with an extension step at } 72{ }^{\circ} \mathrm{C} \text { for } \\
10 \mathrm{~min} \text {. }\end{array}$ \\
\hline $\begin{array}{l}\text { 16S rRNA gene } \\
\text { cloning }\end{array}$ & $\begin{array}{l}\text { Initial denaturation for } 10 \mathrm{~min} \text { at } 95^{\circ} \mathrm{C} \text {, followed by } 35 \text { cycles of } 95^{\circ} \mathrm{C} \text { for } 10 \mathrm{~s}, 60^{\circ} \mathrm{C} \\
\text { for } 15 \mathrm{~s} \text {, and } 72{ }^{\circ} \mathrm{C} \text { for } 20 \mathrm{~s} \text {. The program ended with an extension step at } 72{ }^{\circ} \mathrm{C} \text { for } \\
10 \mathrm{~min} \text {. }\end{array}$ \\
\hline $\begin{array}{l}\text { Reverse } \\
\text { transcription PCR }\end{array}$ & Hold at $37^{\circ} \mathrm{C}$ for $15 \mathrm{~min}$ and $85^{\circ} \mathrm{C}$ for $5 \mathrm{~s}$ \\
\hline 16S rRNA qPCR & $\begin{array}{l}\text { Initial denaturation for } 30 \mathrm{~s} \text { at } 95^{\circ} \mathrm{C} \text {, followed by } 40 \text { cycles of: } 95^{\circ} \mathrm{C} \text { for } 10 \mathrm{~s}, 60^{\circ} \mathrm{C} \text { for } \\
15 \mathrm{~s} \text {, and } 72^{\circ} \mathrm{C} \text { for } 20 \mathrm{~s} \text {. }\end{array}$ \\
\hline $\operatorname{amoA} q \mathrm{PCR}$ & $\begin{array}{l}\text { Initial denaturation for } 30 \mathrm{~s} \text { at } 95^{\circ} \mathrm{C} \text {, followed by } 40 \text { cycles of } 95^{\circ} \mathrm{C} \text { for } 60 \mathrm{~s}, 54{ }^{\circ} \mathrm{C} \text { for } \\
60 \mathrm{~s} \text {, and } 72^{\circ} \mathrm{C} \text { for } 60 \mathrm{~s} \text {. }\end{array}$ \\
\hline
\end{tabular}

qPCR analysis

qPCR was performed using a Roche LC-480 real-time PCR system $(\mathrm{CH})$. A series of 10-fold dilutions of the extract DNA and cDNA were run to assess for possible qPCR inhibition. Inhibition was observed without dilution to test the $16 \mathrm{~S}$ rRNA copy numbers. Thus, a 100fold dilution for $16 \mathrm{~S}$ rRNA was used in the final analysis, and the remaining reactions were performed without dilution (Di et al. 2010). The $16 \mathrm{~S}$ rRNA andamoA genes were quantified using the primers Eub341F/Eub534R (Muyzer et al. 1993) and RottF/RottR (Rotthauwe et al. 1997), respectively, with SYBR ${ }^{\circledR}$ Premix Ex Taq ${ }^{\mathrm{TM}}$ (TaKaRa, Japan). The $20 \mu \mathrm{L}$ of reaction mixture consisted of $10 \mu \mathrm{L}$ of SYBR ${ }^{\circledR}$ Premix Ex Taq ${ }^{\mathrm{TM}}, 0.4 \mu \mathrm{L}$ of each of the forward and reverse primers $(10 \mu \mathrm{M}), 7.2 \mu \mathrm{L}$ of nuclease-free water, and $2 \mu \mathrm{L}$ of template DNA (1 to $10 \mathrm{ng}$ ). The qPCR programs are shown in Table 1. The final qPCR data was generated using the Abs Quant/2nd Derivative Max provided with the Roche LC-480 system.

Standard curves were obtained as follows (Di et al. 2010). In brief, the purified PCR products (16S rRNA andamoA) obtained from the extracted DNA were cloned into plasmid vectors PMD-18T (TaKaRa, Japan), following the manufacturer's protocol. The plasmids extracted from the correct insert clones of each target gene were sequenced. The edited sequences were compared with known sequences in the GenBank to identify the correct constructed plasmid. The concentration of the plasmid DNA was determined using the Nanodrops ND-1000 UVvis spectrophotometer, and the target gene copy numbers were directly calculated from the concentration of the plasmid DNA. The 10-fold serial dilutions of the quantified standard plasmids were subjected to a qPCR assay in triplicate to generate external standard curves. The standard curve efficiency was 0.820 for the $16 \mathrm{~S}$ rRNA gene and 0.915 for the amoA gene. The copy number of the standard plasmids ranged from $2.78 \times 10^{2}$ to $2.78 \times 10^{7}$ copies $/ \mu \mathrm{L}$ for the $16 \mathrm{~S}$ rRNA gene and $1.84 \times 10^{2}$ to $1.84 \times 10^{7}$ copies $/ \mu \mathrm{L}$ for the amoA gene. 


\section{Radial oxygen loss}

After sampling, the plants were carefully separated from the debris and cultivated in the same simulated wastewater. The roots were then placed in a $\mathrm{Ti}^{3+}$ citrate solution for $24 \mathrm{~h}$. The flasks were gently shaken initially to even out the color gradients near the roots, and then $5 \mathrm{~mL}$ of the solution was removed to measure the color reduction using a spectrophotometer at a wavelength of $527 \mathrm{~nm}$. The concentration of the $\mathrm{Ti}^{3+}$ citrate solution was extrapolated according to the standard curve, which was obtained from a serial dilution of $\mathrm{Ti}^{3+}$ citrate solutions with known concentrations. The root oxygen release rate was calculated based on the reduction rate of the concentration of the $\mathrm{Ti}^{3+}$ citrate solution in the incubation flasks as described by Sasikala et al. (2009).

\section{Statistical analysis}

The amount of $\mathrm{O}_{2}\left(\mathrm{mg} / \mathrm{m}^{3} /\right.$ day $)$ provided by ROL was calculated using the following equation:

$$
\text { oxygen concentration }\left(\mathrm{mg} / \mathrm{m}^{3} / \text { day }\right)=\frac{\mathrm{R} \times \mathrm{N} \times \mathrm{M}}{\mathrm{V}} \times 24 \mathrm{~h} \times 10^{-3}
$$

where $R=$ ROL rates $(\mu \mathrm{mol} \mathrm{O} / \mathrm{h} /$ plant), $N=$ number of plants per cell, $M=$ molar mass of oxygen $(32 \mathrm{~g} / \mathrm{mol})$, and $V=$ volume of the cell $\left(\mathrm{m}^{3}\right)$. Statistical analysis was performed using SPSS software. Independent samples $t$ test was carried out to evaluate the statistical differences of the ROL rates between unharvested and harvested plants.

\section{Results and discussion \\ Effluent water parameters}

Figure 2a, b shows the effluent $\mathrm{NH}_{4}{ }^{+}-\mathrm{N}$ and COD concentrations for each microcosm. Two conclusions could be deduced. First, the nutrient concentrations in the cleared wetlands were obviously higher than those in the planted wetlands. It means that the presence of the plants enhanced ammonia oxidation and COD removal in winter. Second, the concentrations of $\mathrm{NH}_{4}{ }^{+}-\mathrm{N}$ and $\mathrm{COD}$ in the planted microcosms were much higher in the harvested cells than those in the unharvested cells. This result implies that harvesting operation decreased the $\mathrm{NH}_{4+}-\mathrm{N}$ and COD removal during the following winter. Previous studies proved that nitrification limitation and low aerobic organic matter decomposition can be induced by low oxygen availability since ammonia oxidation and COD removal are redox-sensitive processes (Control 2001, Johansson et al. 2004; Wu et al. 2001). Therefore, the effluent oxygen concentrations were detected to explain these phenomena (as shown in Table 2). Our results showed that the DO concentrations in the influents were high during the low winter temperature. Even the cleared microcosms had a higher effluent DO concentration than the planted microcosms, indicating that enough oxygen was supplied to the systems. Previous studies found that microbial bacteria participate in removal processes (Faulwetter et al. 2009). 
Thus, we inferred that microbial variation and temperature played a key role in the microcosm. Further discussions are presented in the following section.

Table 2 Effluent temperatures $\left({ }^{\circ} \mathrm{C}\right)$ and dissolved oxygen concentrations (mg/L) of the three experiments (mean $\pm \mathrm{SD}, n=3$ )

\begin{tabular}{lllllllll}
\hline Day & Influent & \multicolumn{3}{c}{ Unharvested } & \multicolumn{2}{l}{ Harvested } & \multicolumn{2}{l}{ Cleared } \\
\cline { 2 - 9 } & T & DO & T & DO & T & DO & T & DO \\
$\mathbf{7}$ & $11.4 \pm 0.5$ & $6.91 \pm 0.3$ & $10.1 \pm 0.1$ & $1.26 \pm 0.5$ & $10.2 \pm 0.3$ & $2.14 \pm 0.2$ & $10.1 \pm 0.1$ & $2.94 \pm 0.1$ \\
$\mathbf{1 4}$ & $8.1 \pm 0.2$ & $7.7 \pm 0.2$ & $7.1 \pm 0.1$ & $0.93 \pm 0.2$ & $7.5 \pm 0.1$ & $1.24 \pm 0.6$ & $7.8 \pm 0.3$ & $1.33 \pm 0.2$ \\
$\mathbf{2 1}$ & $6.1 \pm 0.3$ & $7.7 \pm 0.1$ & $4.7 \pm 0.5$ & $1.18 \pm 0.1$ & $4.7 \pm 0.5$ & $0.91 \pm 0.1$ & $4.9 \pm 0.1$ & $2.17 \pm 0.5$ \\
$\mathbf{2 8}$ & $6.8 \pm 0.1$ & $8.63 \pm 0.5$ & $4.1 \pm 0.1$ & $1.56 \pm 0.8$ & $4.1 \pm 0.1$ & $1.23 \pm 0.5$ & $4.6 \pm 0.3$ & $4.26 \pm 0.1$ \\
$\mathbf{3 5}$ & $5.4 \pm 0.1$ & $9.43 \pm 0.1$ & $3.3 \pm 0.2$ & $1.25 \pm 0.1$ & $3.3 \pm 0.4$ & $2.28 \pm 0.1$ & $3.8 \pm 0.2$ & $4.99 \pm 0.6$ \\
$\mathbf{4 2}$ & $0 \pm 0.1$ & $10.7 \pm 0.5$ & $3.5 \pm 0.3$ & $3.26 \pm 0.2$ & $3.5 \pm 0.2$ & $3.95 \pm 0.5$ & $3.9 \pm 0.1$ & $6.58 \pm 0.5$ \\
\hline
\end{tabular}
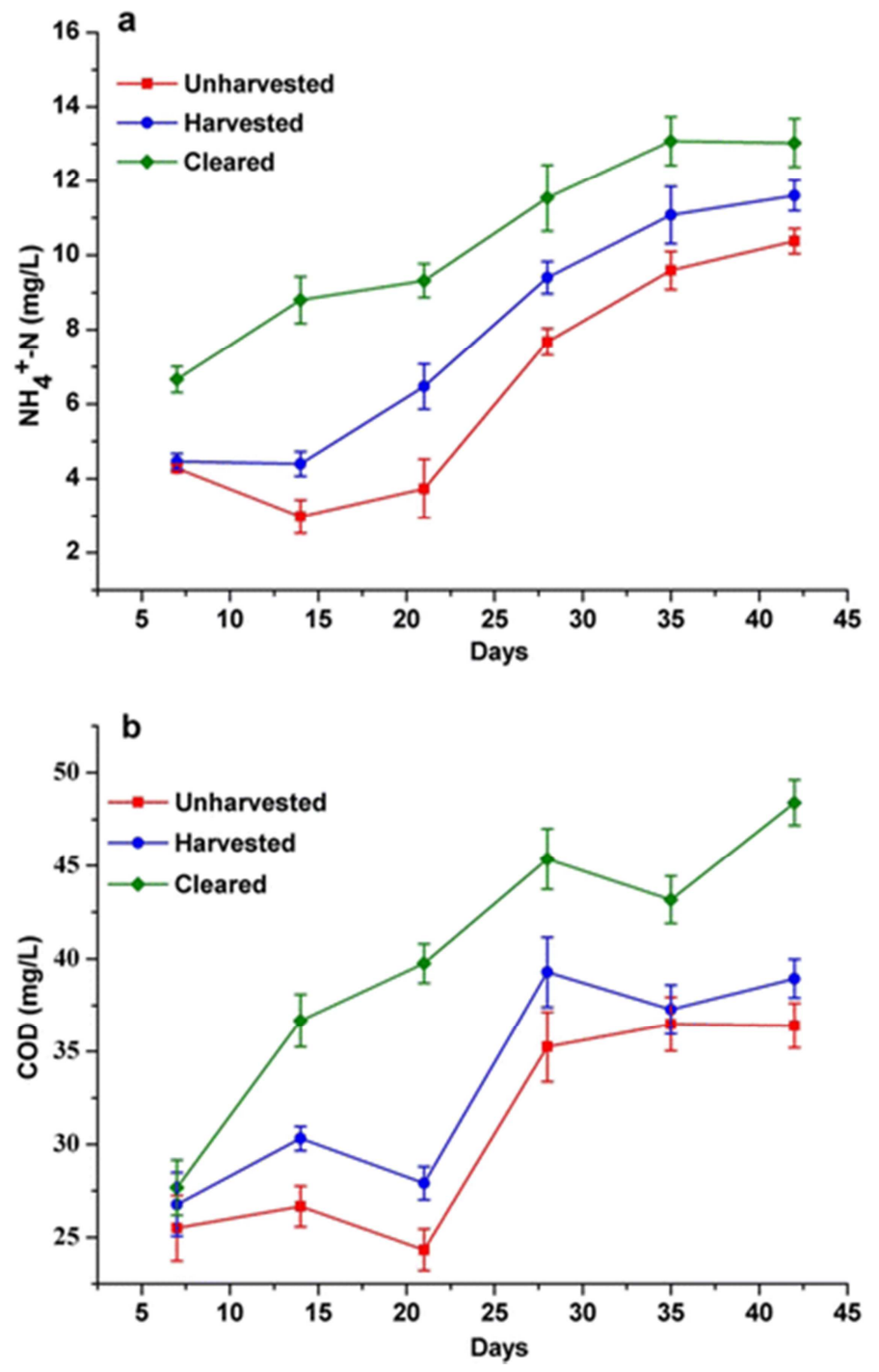

Fig. 2 Comparison of $\mathrm{NH}_{4}{ }^{+}-\mathrm{N}(\mathbf{a})$ and COD (b) concentrations in effluent water for the three types of experiments at 7-day retention time. Error bars represent standard error $(n=3)$ 


\section{Microbial abundance and activity}

Figure 3 presents the differences of ammonia oxidizing bacteria (AOB) and the total bacteria abundance among the wetlands in sands.
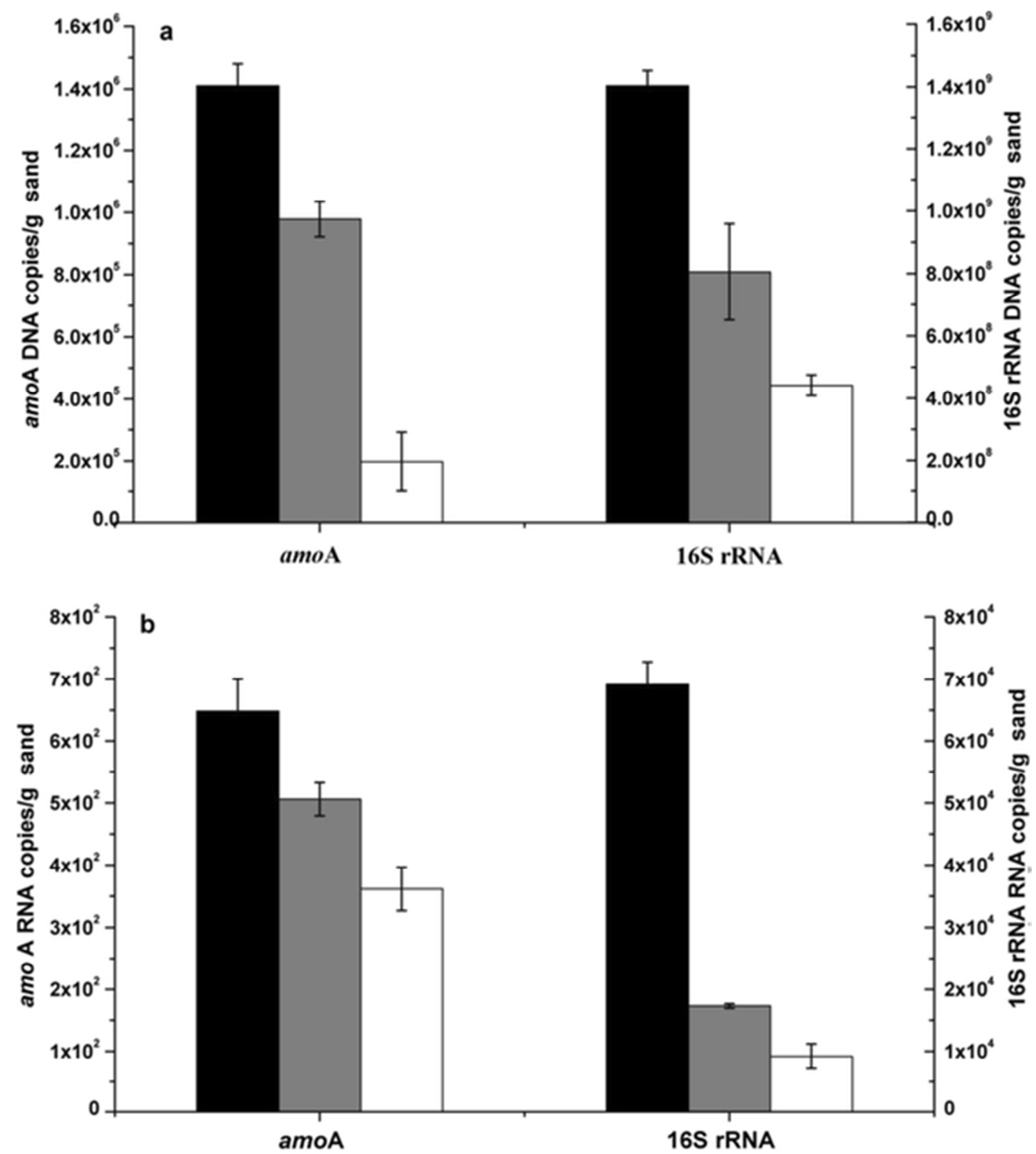

Fig. 3 DNA (a) and RNA (b) copy numbers for amoA of AOB and 16S rRNA of total bacterial in top sands (unharvested (black), harvested (gray), and cleared (white)). Error bars represent standard error $(n=3)$

At low temperatures, the total bacteria copy numbers in unharvested wetlands based on the 16S rRNA gene was $1.41 \pm 0.04 \times 10^{9}$ copies/g sand, which was 1.7 and 3.1 times that of the harvested and cleared units, respectively (Fig. 3a). The results indicated that the winter removal efficiency corresponded with the microbial abundance. Similar trends were observed for the microbial activity during winter (Fig. 3b). The total bacterial activity was indicated by the RNA copy numbers of 16S rRNA; the activity was highest in the unharvested wetlands 
$\left(4.75 \pm 0.02 \times 10^{4}\right.$ copies $\left./ g\right)$, followed by the harvested wetlands $\left(1.19 \pm 0.03 \times 10^{4}\right.$ copies $\left./ \mathrm{g}\right)$. Minimal microbial activity was observed in the cleared wetlands $\left(0.63 \pm 0.14 \times 10^{4}\right.$ copies $\left./ \mathrm{g}\right)$. Other studies indicated that mRNA levels respond to several environmental conditions, such as ammonia supplementation, ammonia deprivation, carbon deprivation, and metal stress (Aoi et al. 2004; Radniecki et al. 2009; Wei et al. 2006). In the present study, both the microbial abundance and activity corresponded with the effluent removal efficiency. Higher bacteria abundance and enhanced microbial activity were observed in planted microcosms compared with the cleared ones. This result can be explained by the capacity of large plant root systems to support the attachment of microorganisms, increasing their populations relative to the unplanted wetlands (Brix 1997). Besides, the relative amount of root exudates secreted from the belowground tissue may also have a positive impact on the microorganisms (Duarte et al. 2005; Jensen et al. 2007; Munch et al. 2007).
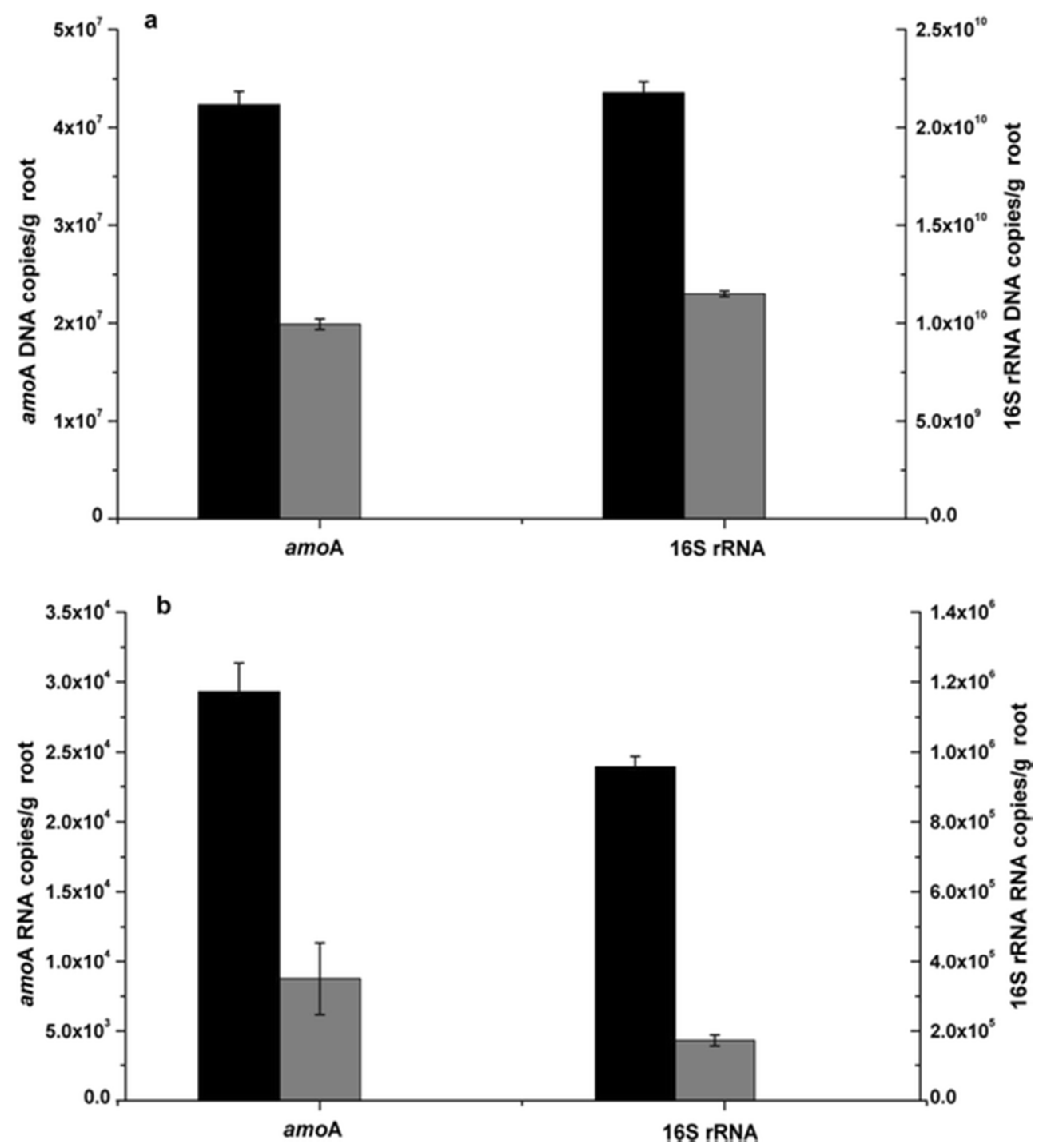

Fig. 4 DNA (a) and RNA (b) copy numbers for amoA of AOB and 16S rRNA of total bacterial on root surfaces (unharvested (black), harvested (gray), and cleared (white)). Error bars represent standard error $(n=3)$ 
Figure 4 shows the number of DNA and RNA copies, respectively, on the root surfaces. Because the plants were completely removed in the cleared wetlands, no data could be shown for the cleared samples. The microbial abundance and activity in the sands were only $10 \%$ that of the root surfaces (Figs. 3 and 4). The rhizome resources obtained from the roots possess enhancing effects that can increase the microbial biomass in the rhizosphere (Stottmeister et al. 2003). Plant roots support high levels of microbial abundance and activity primarily because they are sites of oxygen release and root exudation (Bürgmann et al. 2005; Bais et al. 2006; Munch et al. 2007). Hence, the differences in the microbial abundance and activity on the root surfaces of plants cultured in the wetlands may be explained by the relative reduced oxygen and organic carbon (exudates) leakage from roots of harvested plants.

We also detected that the amoA gene of AOB could give some insights into the observed microbial differences. Our results showed that the amoA gene copy numbers indicative of AOB were $1.41 \pm 0.01 \times 10^{6}$ copies $/ g$, which is 1.4 and 7.2 times those of the harvested and cleared ones (Fig. 3a). The activity of the AOB was highest in the unharvested wetlands $\left(6.48 \pm 0.52 \times 10^{2}\right.$ copies/g), followed by the harvested $\left(5.06 \pm 0.03 \times 10^{2}\right.$ copies/g) and the cleared $\left(3.62 \pm 0.03 \times 10^{2}\right.$ copies/g) ones (Fig. 3b). These results have several implications. First, despite the high oxygen concentration in the effluent of cleared microcosms, more aerobic bacteria and microbial activity were observed in the planted ones, most likely as a result of root leakage. Second, plants with harvested aboveground biomass seemed to have a negative effect on the abundance of aerobic bacteria probably due to a relative reduction in the amount of secreted exudates from the belowground tissue as compared to the unharvested plants. Moreover, the AOB were ten times more abundant with higher activity on the root surfaces of unharvested plants (Figs. 3 and 4).

\section{Radial oxygen loss}

The ROL rates were detected at different temperatures shown in Fig. 5. The results showed that the unharvested units had higher oxygen release rates than the harvested ones. The ROL values for the unharvested units changed from 0.59 to $0.05 \mu \mathrm{mol} \mathrm{O}_{2} / \mathrm{h} / \mathrm{plant}$ as the temperature decreased, and a change of 0.52 to $0.01 \mu \mathrm{mol} \mathrm{O}_{2} / \mathrm{h} /$ plant was observed for the harvested ones. The aboveground biomass provides oxygen to the belowground tissue through the aerenchyma (Caffrey and Kemp 1991; Connell et al. 1999; Pedersen et al. 1998, Brodersen et al. 2014a). Most of the oxygen transported to the roots is of photosynthetic origin (Hupfer and Dollan 2003; Sand-Jensen et al. 1982; Sorrell and Dromgoole 1988), and the oxygen transport within the aerenchyma is mainly through diffusion (Borum et al. 2006; Schuette et al.1994; Sorrell and Dromgoole 1988). Thus, irradiance (Connell et al. 1999; Flessa 1994), biomass (Caffrey and Kemp 1991; Kemp and Murray 1986), leaf area index (Connell et al. 1999), and diffusion pathways (Connell et al. 1999) have been identified as ROL-determining factors. Our results showed that harvesting aboveground biomass before winter could decrease the oxygen released from roots. The differences were significant when 
the average temperature was above $4{ }^{\circ} \mathrm{C}\left(9.43 \pm 0.60\right.$ to $\left.5.56 \pm 1.78{ }^{\circ} \mathrm{C}, p<0.05\right)$. Previous studies suggested that higher oxygen content in wetlands creates better conditions for microbial processes (Faulwetter et al. 2009). In the present work, we found that higher ROL rates created better conditions for aerobic bacteria (as shown in the Materials and methods section) during winter. Ingemann Jensen et al. (2005) studied the oxic microniches around the roots of the seagrass Zostera marina L. via planar optodes and microelectrodes. They found that the ROL rates are generally highest in the subapical region of roots and decrease proportionally with the distance from the root apex. Oxygen leakage maintains an oxic microzone around the apical root meristem, thereby creating spatiotemporal oxic microniches in the sediment around actively growing roots (Brodersen et al. 2014b). Thus, root surfaces have a better aerobic environment than non-rhizosphere sands. Our results show that more aerobic bacteria with higher activity were present on root surfaces, as compared with those on sands, which agrees with several previous studies (Gagnon et al. 2007; IasurKruh et al. 2010; Wang et al. 2012b). These results confirm that plant ROL has an important effect on microbial abundance and activity during winter (Wu et al. 2011).

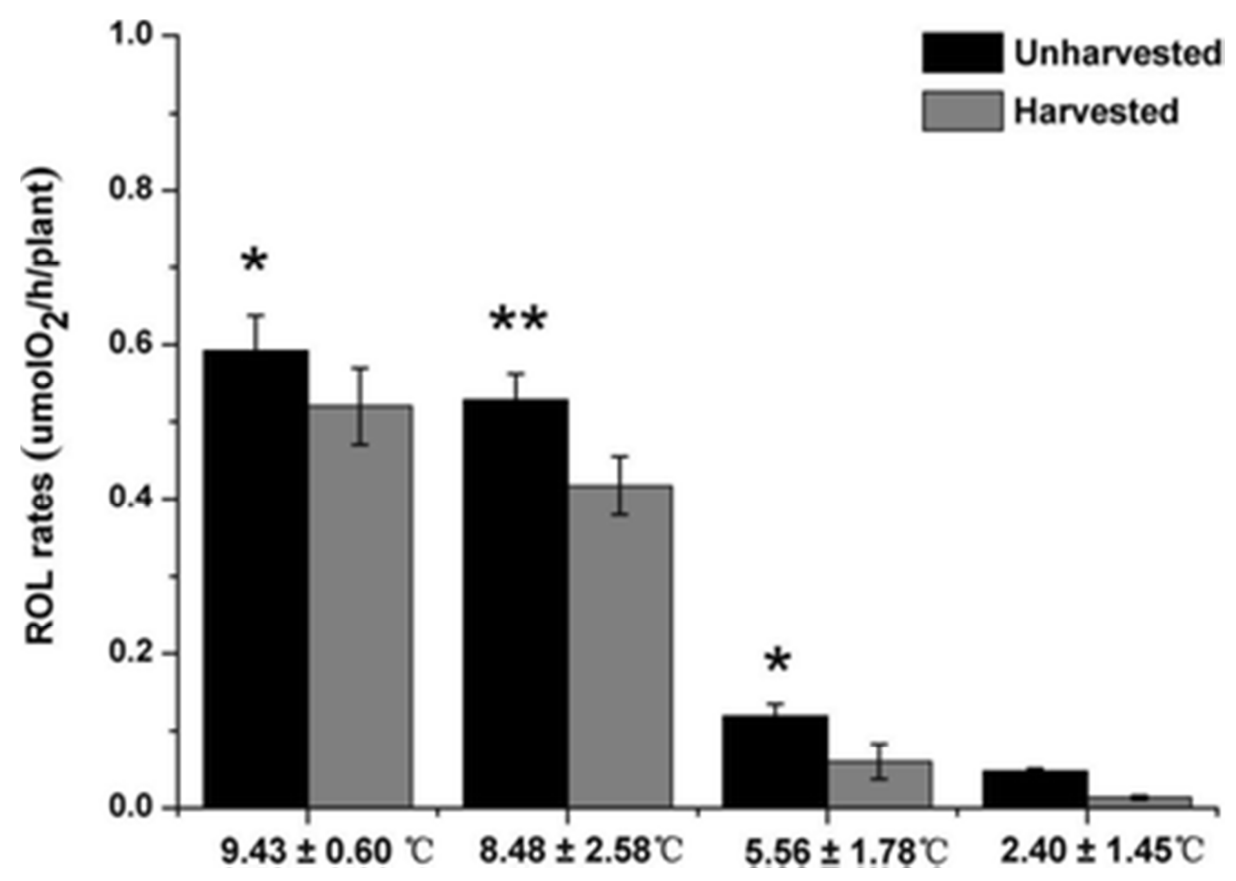

Fig. 5 ROL rates of unharvested and harvested plants at different temperature stages. $* p<0.05, * * p<0.01$. Error bars represent standard error $(n=3)$

A wide range of root oxygen release rates by using different methods and experimental conditions has been published for $P$. australis; these values range from 20 to $5120 \mathrm{mg}$ $\mathrm{O}_{2} / \mathrm{m}^{2} /$ day (Armstrong and Armstrong1990; Wiessner et al. 2006). Our results showed that 18.07 to $227.98 \mathrm{mg} \mathrm{O}_{2} / \mathrm{m}^{3} /$ day was released from the unharvested wetlands during winter, and the harvested units released 5.1 to $200.16 \mathrm{mg} \mathrm{O}_{2} / \mathrm{m}^{3} /$ day (Table 3). Given that $4.5 \mathrm{mg}$ $\mathrm{O}_{2}$ is required per milligram of nitrified $\mathrm{N}$, ROL could theoretically supply 4.02 to $50.66 \mathrm{mg}$ $\mathrm{NO}_{3}{ }^{-}-\mathrm{N} / \mathrm{m}^{3} /$ day of nitrified $\mathrm{N}$ (below $4{ }^{\circ} \mathrm{C}$ ) in the unharvested wetlands, as compared with 
1.14 to $44.48 \mathrm{mg} \mathrm{NO}_{3}{ }^{-}-\mathrm{N} / \mathrm{m}^{3} /$ day in the harvested ones. Hence, the different ROL rates caused by harvesting directly influenced the nitrified $\mathrm{N}$ in the planted wetlands.

Table $3 \mathrm{O}_{2}$ concentration ( $\mathrm{mg} / \mathrm{m}^{3} /$ day) provided from ROL of unharvested and harvested plants at different temperature stages (mean $\pm \mathrm{SD}, n=3$ )

\begin{tabular}{lllll}
\hline Planted unit & \multicolumn{3}{l}{ Temperature stage } & \\
\cline { 2 - 5 } & $\left(\mathbf{9 . 4 3} \pm \mathbf{0 . 6 0}{ }^{\circ} \mathbf{C}\right)$ & $\left(\mathbf{8 . 4 8} \pm \mathbf{2 . 5 8}{ }^{\circ} \mathbf{C}\right)$ & $\left(\mathbf{5 . 5 6} \pm \mathbf{1 . 7 8}^{\circ} \mathbf{C}\right)$ & $\left(\mathbf{2 . 4 0} \pm \mathbf{1 . 4 5}{ }^{\circ} \mathbf{C}\right)$ \\
Unharvested & $227.98 \pm 17.57$ & $203.13 \pm 13.37$ & $45.73 \pm 6.08$ & $18.07 \pm 1.30$ \\
Harvested & $200.16 \pm 19.15$ & $160.49 \pm 14.56$ & $22.95 \pm 17.57$ & $5.1 \pm 0.10$ \\
\hline
\end{tabular}

The cleared wetlands had the lowest $\mathrm{NH}_{4}{ }^{+}-\mathrm{N}$ and COD removal efficiency without extra oxygen derived from plants via ROL. That is, the wetlands with macrophytes are obviously superior in terms of root zone oxidation to promote aerobic microbial processes (Stein and Hook 2005; Taylor et al. 2011). The oxygen in the cleared wetlands mainly came from reaeration. However, oxygen diffusion through water is approximately $10^{4}-10^{6}$ times slower than through air (Drew 1981). Oxygen in planted wetlands can be obtained much faster from ROL by internal transfer via the air spaces in the plants (Armstrong 1978; Brix 1997). This phenomenon can explain the better growth conditions of planted wetlands for aerobic bacteria.

Furthermore, when the temperature was below $4{ }^{\circ} \mathrm{C}$, the differences between unharvested and harvested wetlands were not obvious $\left(2.40 \pm 1.45{ }^{\circ} \mathrm{C}, p>0.05\right)$. The ROL rates were almost zero at low temperatures regardless of whether the plants were harvested or not. The lower ROL observed from unharvested plants at low temperatures (i.e., below $4{ }^{\circ} \mathrm{C}$ ) is due to a relatively lower rate of photosynthesis. As the light-independent reactions are highly temperature dependent and the rate of photosynthesis, therefore, increases in direct proportion to temperature until it reaches a temperature optimum for the given plant (Staehr and Borum 2011). Therefore, we speculated that plant roots were still active in winter but that their activity would be limited by low temperatures below $4{ }^{\circ} \mathrm{C}$. In addition, all the effluent DO concentrations of the three kinds of wetlands were increased despite the decreased ROL rates with temperature reduction (Table 2). Figure 2shows that although the oxygen concentrations were increased, the removal efficiency decreased in all wetlands and differences still existed. Therefore, ROL had a potential influence on the microbial processes; its long-lasting and cumulative effects could not be ignored, even when the ROL decreased as the temperature was reduced to below $4{ }^{\circ} \mathrm{C}$. Besides, the potential influence of root exudates secreted from the belowground tissue was also most likely important for the microbial processes and will be detected in detail in our future work.

\section{Conclusion}

Our results indicated that winter ROL significantly affect microbial abundance and activity in wetlands and thus played an important role in nutrient removal. Besides, late autumn 
harvesting of aboveground biomass has negative effects on plant ROL, as well as the microbial population and activity during the following winter. Given the considerable ROL rates before the temperature was reduced to below $4{ }^{\circ} \mathrm{C}$, it is suggested that harvesting should be carried out after the temperature was reduced to below $4{ }^{\circ} \mathrm{C}$, rather than at the end of autumn.

\section{Acknowledgments}

This work was supported by the Independent Innovation Foundation of Shandong University (2012JC029), the Natural Science Foundation for Distinguished Young Scholars of Shandong Province (JQ201216), and the National Water Special Project (2012ZX07203-004).

\section{References}

1. Aoi Y, Masaki Y, Tsuneda S, Hirata A (2004) Quantitative analysis of amoA mRNA expression as a new biomarker of ammonia oxidation activities in a complex microbial community. Lett Appl Microbiol 39:477-482

2. APHA, AWWA, WEF (2002) Standard methods for the examination of water and wastewater, 20th ed. American Public Health Association, American Water Works association and Environment Federation, Washington, D.C

3. Armstrong W (1978) Root aeration in the wetland condition. Plant Life Anaerobic Environ 1:197

4. Armstrong J, Armstrong W (1990) Light-enhanced convective throughflow increases oxygenation in rhizomes and rhizosphere of Phragmites australis (Cav.) Trin. ex Steud. New Phytol 114:121-128

5. Armstrong J, Armstrong W, Beckett PM (1992) Phragmites australis: Venturi-and humidity-induced pressure flows enhance rhizome aeration and rhizosphere oxidation. New Phytol 120:197-207

6. Asaeda T, Karunaratne S (2000) Dynamic modeling of the growth of Phragmites australis: model description. Aquat Bot 67:301-318

7. Asaeda T, Rajapakse L, Manatunge J, Sahara N (2006) The effect of summer harvesting of Phragmites australis on growth characteristics and rhizome resource storage. Hydrobiologia 553:327-335

8. Bais HP, Weir TL, Perry LG, Gilroy S, Vivanco JM (2006) The role of root exudates in rhizosphere interactions with plants and other organisms. Annu Rev Plant Biol 57:233266

9. Białowiec A, Davies L, Albuquerque A, Randerson PF (2012) The influence of plants on nitrogen removal from landfill leachate in discontinuous batch shallow constructed wetland with recirculating subsurface horizontal flow. Ecol Eng 40:44-52 
10. Borum J, Sand-Jensen K, Binzer T, Pedersen O, Greve TM (2006) Oxygen movement in seagrasses. In: Seagrasses: biology, ecology and Conservation. Springer, the Netherlands, p 255-270

11. Brix H (1997) Do macrophytes play a role in constructed treatment wetlands? Water Sci Technol 35:11-17

12. Brix H, Schierup H-H (1990) Soil oxygenation in constructed reed beds: the role of macrophyte and soil-atmosphere interface oxygen transport. Constructed wetlands in water pollution control 53-66

13. Brodersen KE, Nielsen DA, Ralph PJ, Kühl M (2014a) Oxic microshield and local pH enhancement protects Zostera muelleri from sediment derived hydrogen sulphide. New Phytol. doi:10.1111/nph.13124

14. Brodersen KE, Nielsen DA, Ralph PJ, Kühl M (2014b) A split flow chamber with artificial sediment to examine the below ground microenvironment of aquatic macrophytes. Mar Biol 161:2921-2930

15. Bürgmann H, Meier S, Bunge M, Widmer F, Zeyer J (2005) Effects of model root exudates on structure and activity of a soil diazotroph community. Environ Microbiol 7:1711-1724

16. Caffrey J, Kemp W (1991) Seasonal and spatial patterns of oxygen production, respiration and root-rhizome release in Potamogeton perfoliatus L. and Zostera marina L. Aquat Bot 40:109-128

17. Calheiros C, Teixeira A, Pires C, Franco A, Duque A, Crispim L, Moura S, Castro P (2010) Bacterial community dynamics in horizontal flow constructed wetlands with different plants for high salinity industrial wastewater polishing. Water Res 44:50325038

18. Connell EL, Colmer TD, Walker DI (1999) Radial oxygen loss from intact roots of Halophila ovalis as a function of distance behind the root tip and shoot illumination. Aquat Bot 63:219-228

19. Control ISGoUnMiWP (2001) Constructed wetlands for pollution control: processes, performance, design and operation. Iwa, London UK

20. Di HJ, Cameron KC, Shen JP, Winefield CS, O'Callaghan M, Bowatte S, He JZ (2010) Ammonia-oxidizing bacteria and archaea grow under contrasting soil nitrogen conditions. FEMS Microb Ecol 72:386-394

21. Dickopp J, Kazda M, Č́́žková H (2011) Differences in rhizome aeration of Phragmites australis in a constructed wetland. Ecol Eng 37:1647-1653

22. Drew MC (1981) Plant responses to anaerobic conditions in soil and solution culture. Comment Plant Sci 2:209-223 
23. Duarte CM, Holmer M, Marba N (2005) Plant-microbe interactions in seagrass meadows. In: Interactions between macro-and microorganisms in marine sediments. American Geophysical Union, Washington, DC, p 31-60

24. Faulwetter JL, Gagnon V, Sundberg C, Chazarenc F, Burr MD, Brisson J, Camper AK, Stein OR (2009) Microbial processes influencing performance of treatment wetlands: a review. Ecol Eng 35:987-1004

25. Faulwetter JL, Burr MD, Parker AE, Stein OR, Camper AK (2013) Influence of season and plant species on the abundance and diversity of sulfate reducing bacteria and ammonia oxidizing bacteria in constructed wetland microcosms. Microb Ecol 65:111127

26. Flessa H (1994) Plant-induced changes in the redox potential of the rhizospheres of the submerged vascular macrophytes Myriophyllum verticillatum L. and Ranunculus circinatus L. Aquat Bot 47:119-129

27. Gagnon V, Chazarenc F, Comeau Y, Brisson J (2007) Influence of macrophyte species on microbial density and activity in constructed wetlands. Water Sci Technol 56:249_ 254

28. Granéli W, Weisner SE, Sytsma MD (1992) Rhizome dynamics and resource storage in Phragmites australis. Wetl Ecol Manag 1:239-247

29. Hupfer M, Dollan A (2003) Immobilisation of phosphorus by iron-coated roots of submerged macrophytes. Hydrobiologia 506:635-640

30. Iasur-Kruh L, Hadar Y, Milstein D, Gasith A, Minz D (2010) Microbial population and activity in wetland microcosms constructed for improving treated municipal wastewater. Microb Ecol 59:700-709

31. Ingemann Jensen S, Kühl M, Glud RN, Jørgensen LB, Priemé A (2005) Oxic microzones and radial oxygen loss from roots of Zostera marina. Mar Ecol Prog Ser Online 293:49_ 58

32. Jensen SI, Kühl M, Priemé A (2007) Different bacterial communities associated with the roots and bulk sediment of the seagrass Zostera marina. FEMS Microb Ecol 62:108-117

33. Jinadasa K, Tanaka N, Sasikala S, Werellagama D, Mowjood M, Ng W (2008) Impact of harvesting on constructed wetlands performance-a comparison between Scirpus grossus and Typha angustifolia. J Environ Sci Health A 43:664-671

34. Johansson A, Gustavsson A-M, Öquist M, Svensson B (2004) Methane emissions from a constructed wetland treating wastewater-seasonal and spatial distribution and dependence on edaphic factors. Water Res 38:3960-3970

35. Kadlec RH, Wallace S (2008) Treatment wetlands. CRC, Boca Raton, FL 
36. Kemp WM, Murray L (1986) Oxygen release from roots of the submersed macrophyte Potamogeton perfoliatusL.: Regulating factors and ecological implications. Aquat Bot 26:271-283

37. Munch C, Neu T, Kuschk P, Roske I (2007) The root surface as the definitive detail for microbial transformation processes in constructed wetlands-a biofilm characteristic. Water Sci Technol 56:271-276

38. Muyzer G, De Waal EC, Uitterlinden AG (1993) Profiling of complex microbial populations by denaturing gradient gel electrophoresis analysis of polymerase chain reaction-amplified genes coding for 16S rRNA. Appl Environ Microbiol 59:695-700

39. Pedersen O, Borum J, Duarte CM, Fortes MD (1998) Oxygen dynamics in the rhizosphere of Cymodocea rotundata. Mar Ecol Prog Ser 169:283-288

40. Radniecki TS, Semprini L, Dolan ME (2009) Expression of merA, amoA and hao in continuously cultured Nitrosomonas europaea cells exposed to zinc chloride additions. Biotech Bioeng 102:546-553

41. Rotthauwe JH, Witzel KP, Liesack W (1997) The ammonia monooxygenase structural gene amoA as a functional marker: molecular fine-scale analysis of natural ammoniaoxidizing populations. Appl Environ Microbiol 63:4704-4712

42. Sand-Jensen K, Prahl C, Stokholm H (1982) Oxygen release from roots of submerged aquatic macrophytes. Oikos 38:349-354

43. Sasikala S, Tanaka N, Wah Wah H, Jinadasa K (2009) Effects of water level fluctuation on radial oxygen loss, root porosity, and nitrogen removal in subsurface vertical flow wetland mesocosms. Ecol Eng 35:410-417

44. Schuette J, Klug M, Klomparens K (1994) Influence of stem lacunar structure on gas transport: relation to the oxygen transport potential of submersed vascular plants. Plant Cell Environ 17:355-365

45. Sorrell B, Dromgoole F (1988) Oxygen transport in the submerged freshwater macrophyte Egeria densa planch. II. Role of lacunar gas pressures. Aquat Bot 31:93-106

46. Staehr P, Borum J (2011) Seasonal acclimation in metabolism reduces light requirements of eelgrass (Zostera marina). J Exp Mar Bio Eco 407:139-146

47. Stein OR, Hook PB (2005) Temperature, plants, and oxygen: how does season affect constructed wetland performance? J Environ Sci Health 40:1331-1342

48. Stottmeister U, Wießner A, Kuschk P, Kappelmeyer U, Kästner M, Bederski O, Müller R, Moormann H (2003) Effects of plants and microorganisms in constructed wetlands for wastewater treatment. Biotechnol Adv 22:93-117

49. Tanaka N, Yutani K, Aye T, Jinadasa K (2007) Effect of broken dead culms of Phragmites australis on radial oxygen loss in relation to radiation and temperature. Hydrobiologia 583:165-172 
50. Taylor CR, Hook PB, Stein OR, Zabinski CA (2011) Seasonal effects of 19 plant species on COD removal in subsurface treatment wetland microcosms. Ecol Eng 37:703-710

51. Toet S, Bouwman M, Cevaal A, Verhoeven JT (2005) Nutrient removal through autumn harvest of Phragmites australis and Thypha latifolia shoots in relation to nutrient loading in a wetland system used for polishing sewage treatment plant effluent. J Environ Sci Health 40:1133-1156

52. Ueckert J, Hurek T, Fendrik I, Niemann E-G (1990) Radial gas diffusion from roots of rice (Oryza sativa L.) and Kallar grass (Leptochloa fusca L. Kunth), and effects of inoculation with Azospirillum brasilense Cd. Plant Soil 122:59-65

53. Valkama E, Lyytinen S, Koricheva J (2008) The impact of reed management on wildlife: a meta-analytical review of European studies. Biol Conserv 141:364-374

54. Van Bodegom P, Stams F, Mollema L, Boeke S, Leffelaar P (2001) Methane oxidation and the competition for oxygen in the rice rhizosphere. Appl Environ Microbiol 67:3586-3597

55. Vymazal J (2010) Constructed wetlands for wastewater treatment: five decades of experience†. Environ Sci Technol 45:61-69

56. Wang F, Liu Y, Ma Y, Wu X, Yang H (2012a) Characterization of nitrification and microbial community in a shallow moss constructed wetland at cold temperatures. Ecol Eng 42:124-129

57. Wang R, Baldy V, Périssol C, Korboulewsky N (2012b) Influence of plants on microbial activity in a vertical-downflow wetland system treating waste activated sludge with high organic matter concentrations. J Environ Manag 95:S158-S164

58. Wei X, Yan T, Hommes NG, Liu X, Wu L, McAlvin C, Klotz MG, Sayavedra-Soto LA, Zhou J, Arp DJ (2006) Transcript profiles of Nitrosomonas europaea during growth and upon deprivation of ammonia and carbonate. FEMS Microbiol Lett 257:76-83

59. Wiessner A, Kuschk P, Kappelmeyer U, Bederski O, Müller R, Kästner M (2006) Influence of helophytes on redox reactions in their rhizosphere, Phytoremediation Rhizoremediation. Springer, the Netherlands, p 69-82

60. Wu M-Y, Franz EH, Chen S (2001) Oxygen fluxes and ammonia removal efficiencies in constructed treatment wetlands. Water Environ Res 661-666

61. Wu S, Jeschke C, Dong R, Paschke H, Kuschk P, Knöller K (2011) Sulfur transformations in pilot-scale constructed wetland treating high sulfate-containing contaminated groundwater: a stable isotope assessment. Water Res 45:6688-6698 